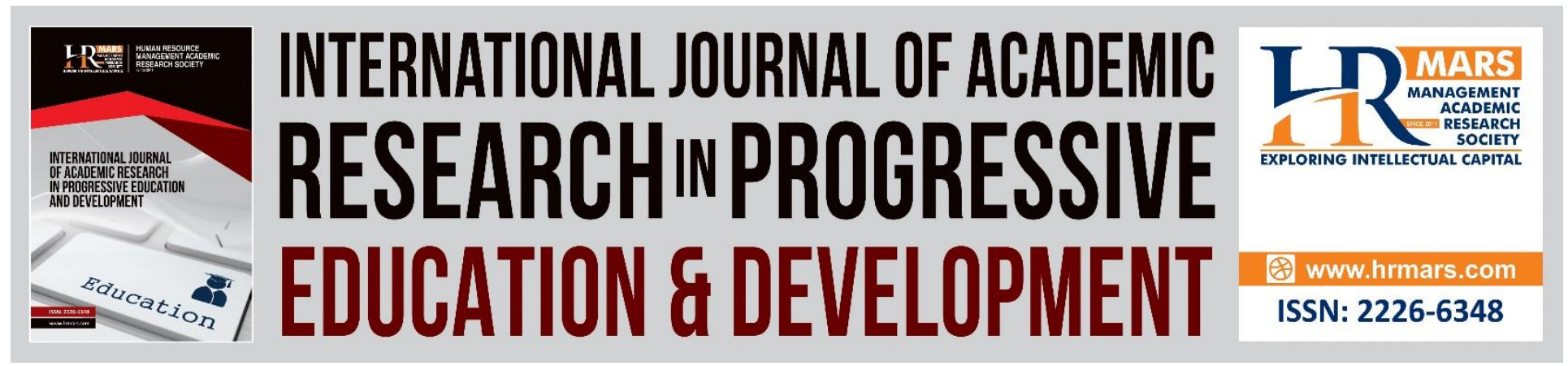

\title{
Gifted Students' Knowledge and Motivation Towards Learning Chemistry: A Case Study at Pusat GENIUS@pintar Negara, Malaysia
}

\section{Suganty A/ P Kanapathy}

To Link this Article: http://dx.doi.org/10.6007/IJARPED/v9-i2/7968

DOI:10.6007/IJARPED/v9-i2/7968

Received: 07 May 2020, Revised: 28 May 2020, Accepted: 21 June 2020

Published Online: 28 July 2020

In-Text Citation: (Kanapathy, 2020)

To Cite this Article: Kanapathy, S. A/ P. (2020). Gifted Students' Knowledge and Motivation Towards Learning Chemistry: A Case Study at Pusat GENIUS@pintar Negara, Malaysia. International Journal of Academic Research in Progressive Education \& Development. 9(2), 722-739.

Copyright: (C) 2020 The Author(s)

Published by Human Resource Management Academic Research Society (www.hrmars.com)

This article is published under the Creative Commons Attribution (CC BY 4.0) license. Anyone may reproduce, distribute, translate and create derivative works of this article (for both commercial and non-commercial purposes), subject to full attribution to the original publication and authors. The full terms of this license may be seen at: http://creativecommons.org/licences/by/4.0/legalcode

Vol. 9(2) 2020, Pg. 722 - 739

http://hrmars.com/index.php/pages/detail/IJARPED JOURNAL HOMEPAGE

Full Terms \& Conditions of access and use can be found at http://hrmars.com/index.php/pages/detail/publication-ethics 


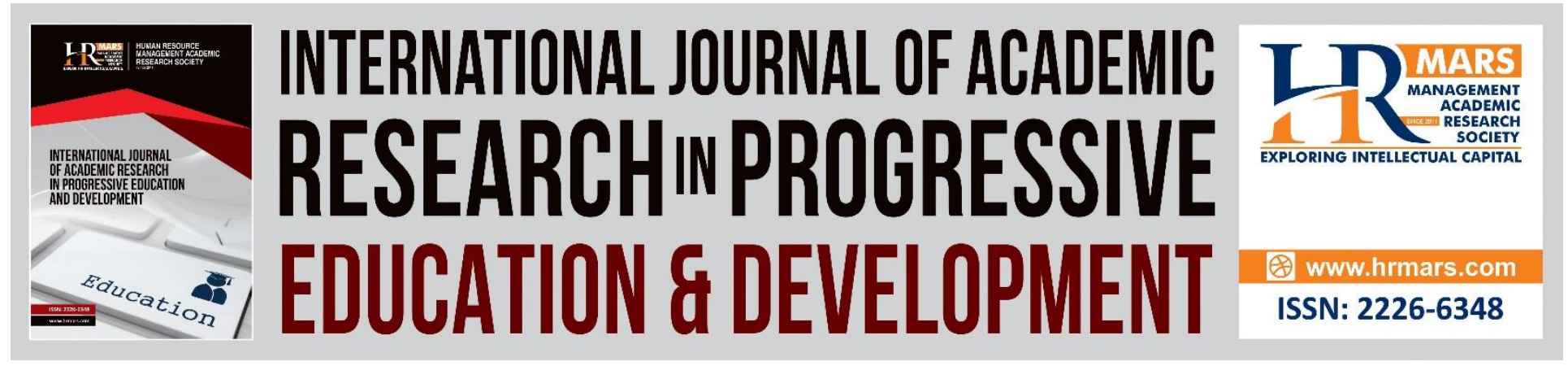

\title{
Gifted Students' Knowledge and Motivation Towards Learning Chemistry: A Case Study at Pusat GENIUS@pintar Negara, Malaysia
}

\author{
Suganty A/ P Kanapathy \\ Pusat GENIUS@pintar Negara, University Kebangsaan Malaysia, 43600 Bangi, Selangor, \\ Malaysia.
}

\begin{abstract}
Nowadays, there are increasing calls for teaching and learning of STEM related field. However, learning of STEM subject, focusing on chemistry at younger age is found to be a challenge among the students. Thus, the purpose of this study is to investigate gifted and talented students' knowledge and motivation towards learning chemistry subject. A total of 71 gifted and talented students, taking chemistry at the age of 12 to 13 years old at Pusat GENIUS@pintar Negara, University Kebangsaan Malaysia were involved in this study. A survey questionnaire was utilized in this study and the instrument employed was Attitude toward Chemistry Lesson Scale and Glynn's motivation model. The collected data were analyzed using Statistical Package for Social Science (SPSS) version 21 involving descriptive and inferential statistics. The result revealed that the students perceived chemistry playing a vital role in many aspects of everyday life. There was no significant difference in the mean of student's knowledge and motivation towards chemistry learning scores for male and female students. The result of the study also indicates that students' knowledge and career motivation has a moderately positive correlation with the highest correlation value. This paper is instrumental in assisting educators to enhance students' knowledge and motivation towards chemistry learning. Therefore, the role of educators is important to bring about changes in terms of knowledge and motivation towards chemistry teaching and learning processes.
\end{abstract}

Keywords: Gifted and Talented, Knowledge, Motivation, Chemistry, Learning.

\section{Introduction}

In this $21^{\text {st }}$ century, literacy in Science, Technology, Engineering, and Mathematics (STEM) is seen as an essential element of science related programs. The teaching and learning of STEM education is being emphasized in the education systems of many countries around the world, including Malaysia. Based on the Ministry of Education (2013) report, Malaysia aims to enhance STEM education in order to be prepared to achieve a developed nation that can face the challenges and demands of STEM driven economy by 2020. In the Malaysian Education Blueprint, as a part of the STEM initiative, the Ministry of Education intends to raise student interest 
through new learning approaches and enhanced curriculum, sharpening skills and abilities of educators to teach the revised curriculum and increase public and learner awareness through national campaigns (Ministry of Education, 2013). Meng, Idris and Eu (2014) found that currently, the enrolment of students in STEM education has continued to decline at the secondary school level in Malaysia. Moreover, in recent years, it was reported that only $42 \%$ of middle school students in Malaysia choose to do Science, including technical and vocational programs at high schools (Ministry of Education, 2016). However, studies show that students who have a high interest in science, mathematics, and engineering in the early years of education are more likely to seek that interest and proceed with their career in a STEM related career (After-School Alliance, 2015). Thus, it is vital to enhance STEM education among the students to think critically and solve problems, besides preparing them as highly skilled workers required by the industry (Rajandram, 2018).

In a study performed in Atlantic Canada among 1448 students, Blotnicky, FranzOdendaal, French \& Joy (2018) evaluated students with low self-efficacy tend to have low interest in STEM education and career. Thus, this study suggested that exposure of students to STEM knowledge and career, able to enhance their eagerness in pursuing career in STEM related areas as a potential choice. Besides that, National Research Council (2009) reported interest and motivation as an important aspect in encouraging students to pursue STEM education since it is able to provide a pathway for students' success in STEM related areas. Loof, Struyf, Boeve-de Pauw and Petegam (2019) evaluated STEM teachers' motivating style and students' motivation and engagement in STEM. It was found that STEM teachers' role is positively interconnected with students' motivation and engagement towards STEM subjects. Thus, teachers' motivating style needs to be considered in stimulating students' motivation and engagement towards STEM education.

STEM education has been classified into various discipline and chemistry is defined as a branch of science education (Samat et al, 2019). Jimoh (2005) states that chemistry is the "central science" of all other sciences and associated with science subjects such as biology, physics, geology, material science and environmental science. In other words, the contribution of chemistry to the world is immense (Ware, 2001). Chemistry education has been recognized for its role in finding answers to various human and socio-economic problems besides developing a more scientifically literate society. Looking at this point of view, chemistry teaching and learning at school level thus play an essential role in raising the students' ability to learn the fundamental concepts of chemistry and understanding of the chemical processes in everyday life (Kolomuc \& Tekin, 2011). Yet, chemistry is often described as an unpopular science subject among the students (Hofstein, Eilks \& Bybee, 2011) due to its difficulty in mastering the subject. Several studies have identified that the abstract concepts of chemistry are a huge challenge faced by the students (Nakhleh, 1992). Moreover, most of the students at the secondary school level think that chemistry as not interesting and not important for their future (Broman, Ekborg \& Johnels, 2011).

Many studies have been conducted on how the motivation of students able to influence their chemistry learning. Concerning the role of motivation in learning science and particularly chemistry as a distinct science subject, Salta and Koulougliotis (2015) have adopted the Science Motivation Questionnaire (II) (SMQII) to study motivational characteristics of 330 Greek 
secondary school students, who learn chemistry for the first time. This study found that comparatively, girls have higher self-determination than boys, irrespective of the age, while in terms of career and intrinsic motivation, girls show a lower value than boys of the same age group. However, it was found that lower secondary school students reveal higher grade motivation than upper secondary school students. Ardura and Perez-Bitrian (2018) also adopted SMQII to reveal the effect of motivational variables and previous academic achievement on students' future choice of chemistry among 1060 secondary school Spanish students. It was found that the best predictor of students' choice to study chemistry is career motivation compared to other motivational factors. This study also found significant gender differences in terms of self-efficacy and self-determination. However, these factors are less pertinent to students' choice to learn chemistry.

Gambari, Gbodi, Olakanmi and Abalaka (2016) studied how intrinsic and extrinsic motivation able to enhance the senior secondary school students' achievement in chemistry using computer simulation instructional package and computer tutorial instructional package. The result revealed that students exposed to computer simulation have higher extrinsic and intrinsic motivation and chemistry teachers should employ computer simulation in order to improve students' achievement and motivation. Olic, Adamov and Babic-Kekez (2014) conducted a survey among 236 third grade high school pupils, to identify the levels of motivation for learning chemistry. The result showed individuals with high perceived self-efficiency in learning have higher achievements. Thus, this study concluded motivation as a reliable predictor of academic success. An investigation on how students' motivation and strategy use changed over the course of one semester, revealed that in the classroom students' perception of their confidence to do excel has declined, and students were less likely to believe that chemistry was important or useful to them. This study recommended that the teacher needs to take initiatives to consider how students' motivational processes such as self-efficacy and task value influence the learning process (Zusho, Pintrich \& Coppola, 2003).

Recently, several studies have been conducted in STEM education focusing on chemistry subject in order to understand ways to improve the quality of STEM education. Based on George (2006) views, the ideal way to learn science is depends on the students' attitude. This is because of the development of a positive attitude in learning science able to motivate the student in learning science and pursue science-related careers. According to the Social Cognitive Theory developed by Bandura (1986, 2001), self-regulated learning is believed to be most effective among learners. This only develops when learners understand, monitor, and control their motivation and behavior, driving to expected learning outcomes. Motivation is one of the important aspects that leads and sustains learning behaviors among students. There is a range of motivational components, which could relate to academic success in STEM education. Glynn, Brickman, Armstrong and Taasoobshirazi (2011) proposed that there are five important components in measuring motivation, namely intrinsic motivation, self-determination, selfefficacy, career motivation and grade motivation, with the last two being related to extrinsic motivation. These five components are claimed to be mutually interconnected and able to motivate students towards a positive pathway in learning, besides encouraging and sustain science-learning interest (Glynn et al, 2011). 
Ryan and Deci (2000) refer to intrinsic motivation as doing something because it is inherently satisfying or enjoyable. Intrinsic motivation found to occur spontaneously due to experiences of interest, excitement, and enjoyment (Orvis, Sturges, Tysinger, Riggins \& Landge, 2018). Besides that, Black and Deci (2000) define self-determination as the control that students believe they have over their learning of science subjects, while self-efficacy accounts for the students' confidence that they will succeed in science subjects (Ferrell \& Barbera, 2015). Finally, extrinsic motivation is defined as doing something because it leads to a separable outcome (Ryan \& Deci, 2000). Mazlo et al (2002) state that learning of science involves a tangible product, namely a career and a grade. Arbona (2000) recommended that students' career motivation and grade motivation are mutually developed by impacting each other. Thus, with extrinsic motivation, students perform a task in order to receive an external reward such as obtaining a reward or avoiding a punishment (Ryan \& Deci, 2000; Orvis et al, 2018).

As claimed by Glynn et al (2011), the five components of the motivation model identified as a reflection on the real context of science learning (Shin, Lee \& Ha, 2017). Moreover, the validity and reliability of Glynn's motivation formulation have been established in numerous studies (Glynn et al, 2011). Besides that, in this study, Attitude toward Chemistry Lessons Scale (ATCLS) proposed by Cheung (2009) was also included as the use of the chemistry knowledge component. The present study employs Glynn's motivation components and ATCLS constructions in order to understand Pusat GENIUS@pintar Negara, gifted and talented students' knowledge and motivation towards learning chemistry.

\section{Methodology \\ Respondents}

The respondents of this research comprised of 71 gifted and talented students, selected from random sampling to participate in this study. The selected students were gifted and talented students (12 to 13 years old) of the High School Program at Pusat GENIUS@pintar Negara, University Kebangsaan Malaysia. All the selected respondents were from a science background, taking chemistry subject, besides biology and physics.

High School Program at Pusat GENIUS@pintar Negara, University Kebangsaan Malaysia was selected as study location because this center implements student centred learning practices for teaching and learning of chemistry. Besides that, at Pusat GENIUS@pintar Negara, University Kebangsaan Malaysia classroom environment is created in a way to actively engage gifted and talented students with student centred learning such as independent learning, group discussion and project based learning.

In the teaching of chemistry, in order to actively engage gifted and talented students in learning, differentiation by content, process, product and teaching strategies were being employed. Wallace et al (2012) state that gifted and talented students require a significant extent of challenge in order to impede them unmotivated and bored in class, besides encourage full engagement of the students. Moreover, Sisk (2009) also proposed that the students are able to explore the curriculum in diverse forms based on their own ability level through differentiated classroom learning. Thus, Pusat GENIUS@pintar Negara, University Kebangsaan Malaysia was identified as a suitable place to study gifted and talented students' knowledge and motivation towards learning chemistry. 
INTERNATIONAL JOURNAL OF ACADEMIC RESEARCH IN PROGRESSIVE EDUCATION AND DEVELOPMENT

Vol. 9, No. 2, 2020, E-ISSN: $2226-6348$ @ 2020 HRMARS

\section{Quantitative Approach}

A quantitative approach is used to carry out this research. The research design for this study is a survey, whereby a questionnaire is used as the main instrument to collect data. The survey questions were adapted based on Attitude toward Chemistry Lessons Scale (ATCLS) (Cheung, 2009) and Science Motivation Questionnaire II (SMQII), which was originally designed for USA college students (Glynn et al, 2011), which are the most recent and reliable instruments. As stated in the original validation work by Cheung (2009) and Glynn et al (2011), ATCLS and SMQII are adaptable to different classification of science. The questionnaire used as the main instrument for this research comprises of six constructs that describe knowledge and motivation towards learning chemistry. This questionnaire contains twenty-six items with each construct containing four to five items. A five point scale was used to obtain the responses, starting with 1Strongly Disagree, 2 - Disagree, 3 - Neutral, 4-Agree, and 5-Strongly Agree. Following this section, the questionnaire also included a set of demographic data focussing on age, gender and race.

Before embarking on actual data collection, a pilot test was conducted with 30 gifted and talented students. Based on the data obtained from the pilot study, the Cronbach's alpha coefficient of reliability was derived. Each construct of the instrument was assessed for its reliability separately. According to Taber (2017), the dimensions should have a Cronbach alpha of at least 0.64 to establish adequate reliability of the constructs. The results of the pilot study in this research showed a reliability coefficient of 0.897 for intrinsic motivation, 0.807 for selfdetermination, 0.652 for self-efficacy, 0.930 for career motivation and 0.807 for grade motivation. Also, a coefficient of 0.773 was observed for the knowledge scale. After the pilot study, the main data collection could be conducted more confidently. The questionnaire was personally distributed to all participating gifted and talented students. Each of the respondents took a maximum of 30 minutes to complete the questionnaire. Statistical analysis of the data was conducted using Statistical Package for Social Sciences (SPSS) version 21 in order to determine the frequency, percentage, mean standard deviation, independent sample t-test and Pearson's correlation analysis.

\section{Results and Discusssions Demographic Analysis}

The descriptive analyses of the respondents' demographic background such as age, gender and race are presented in Table 1 . The results of the study showed that the age group of the respondents was 12 and 13 years old, with 13 years old gifted and talented students as the dominant gender ( $n=61,85.9 \%)$. It was also observed that a total of 36 male $(50.7 \%)$ and 35 female (49.3\%) gifted and talented students participated in this study. Among them, 56 are Malay, 8 are Chinese, 5 are Indians and 2 students are from other races. 
INTERNATIONAL JOURNAL OF ACADEMIC RESEARCH IN PROGRESSIVE EDUCATION AND DEVELOPMENT

Vol. 9, No. 2, 2020, E-ISSN: $2226-6348$ @ 2020 HRMARS

Table 1. Demographic analysis.

\begin{tabular}{|c|c|c|c|}
\hline \multicolumn{2}{|c|}{ Characteristics } & N & Percentage, (\%) \\
\hline \multirow{3}{*}{ Age } & 12 & 10 & 14.1 \\
\cline { 2 - 4 } & 13 & 61 & 85.9 \\
\hline \multirow{3}{*}{ Gender } & Male & 36 & 50.7 \\
\cline { 2 - 4 } & Female & 35 & 49.3 \\
\hline \multirow{7}{*}{ Race } & Malay & 56 & 78.9 \\
\cline { 2 - 4 } & Chinese & 8 & 11.3 \\
\cline { 2 - 4 } & Indian & 5 & 7.0 \\
\cline { 2 - 4 } & Others & 2 & 2.8 \\
\hline
\end{tabular}

\section{Chemistry Knowledge}

Figure 1 represents the use of chemistry knowledge in gifted and talented students' daily life. Most of the gifted and talented students with the opinion that chemistry knowledge is useful to interpret many aspects of everyday life (mean=4.31), followed by chemistry knowledge are essential for understanding other courses (mean=4.18) and chemistry as their hope for solving many environmental problems (mean=4.13).

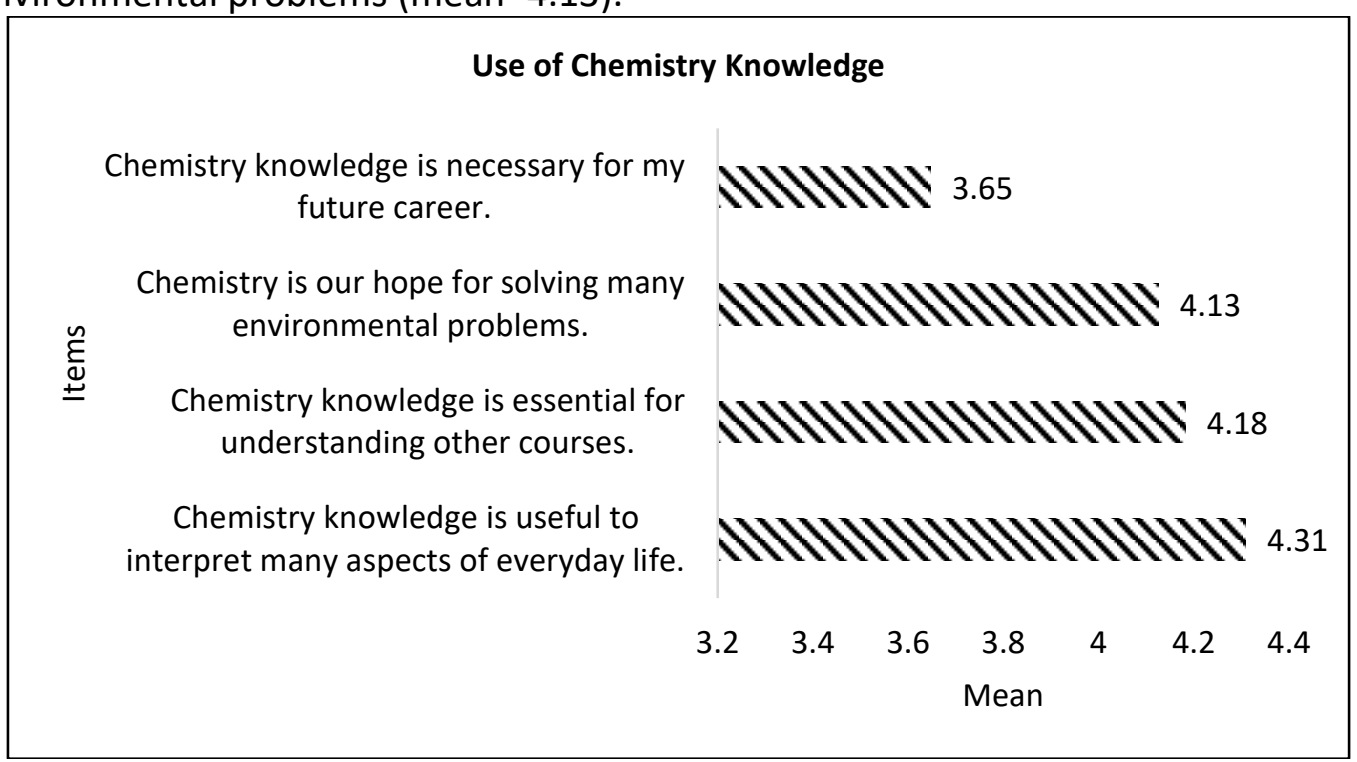

Figure 1. Use of chemistry knowledge in daily life.

Chemistry knowledge is useful to interpret many aspects of everyday life shows the highest mean value because chemistry is seen in our daily life through the foods intake, the air we breathe, cleaning agents, human emotions due to chemical messengers, and objects that we can see or touch (Roy, 2016). Since the role of chemistry is identified on the whole in the everyday life of humans in different aspects, life without chemistry knowledge was identified unattainable. In general, Jimoh (2005) defines chemistry as the mother of all sciences, indicating the knowledge of chemistry is crucial to allow the students to learn other science subjects such as biology, physics, material science, environmental science and geology (Ware, 2001). On the other hand, the lowest mean value was observed in relation to chemistry knowledge is necessary for their 
future career (mean=3.65). This is because the respondents in this study are between 12 to 13 years old, who undergoing a transition phase between childhood and adulthood. Thus, their chemistry knowledge relating to future careers still in the developing phase.

\section{Motivation to Learn Chemistry}

Saribiyik, Altuncekic and Yaman (2004) states that motivation is recognized as an essential key to make learning more effective. This is because students' motivation in learning able to contribute to students' science achievement (Pintrich \& Schunk, 2002) and demonstrate the level of students' effort and interest in learning, regardless of whether the tasks are assigned by the educators or not (Brophy, 2004). Grade motivation to learn chemistry is reported in Figure 2 . The result shows that getting a good chemistry grade is important for the gifted and talented students (mean=4.63). However, the result also reveals that not all students prefer to do better than other students in chemistry test (mean=4.07). The highest mean value shows that the students realize the importance of getting good grades in chemistry and have high motivation to achieve the grade. On the other hand, students' attitude was identified as highly influencing factor for their performance in the science subjects particularly in chemistry (Hassan et al., 2015). Among the components studied, the highest mean value was obtained for the trait from the grade motivation component. This result is in line with previous studies conducted at the secondary school level, namely in Greek (Salta \& Koulougliotis, 2015), German (Schumm \& Bogner, 2016) and Spanish (Ardura \& Perez-Bitrian, 2018), where the students scored higher value in grade motivation.

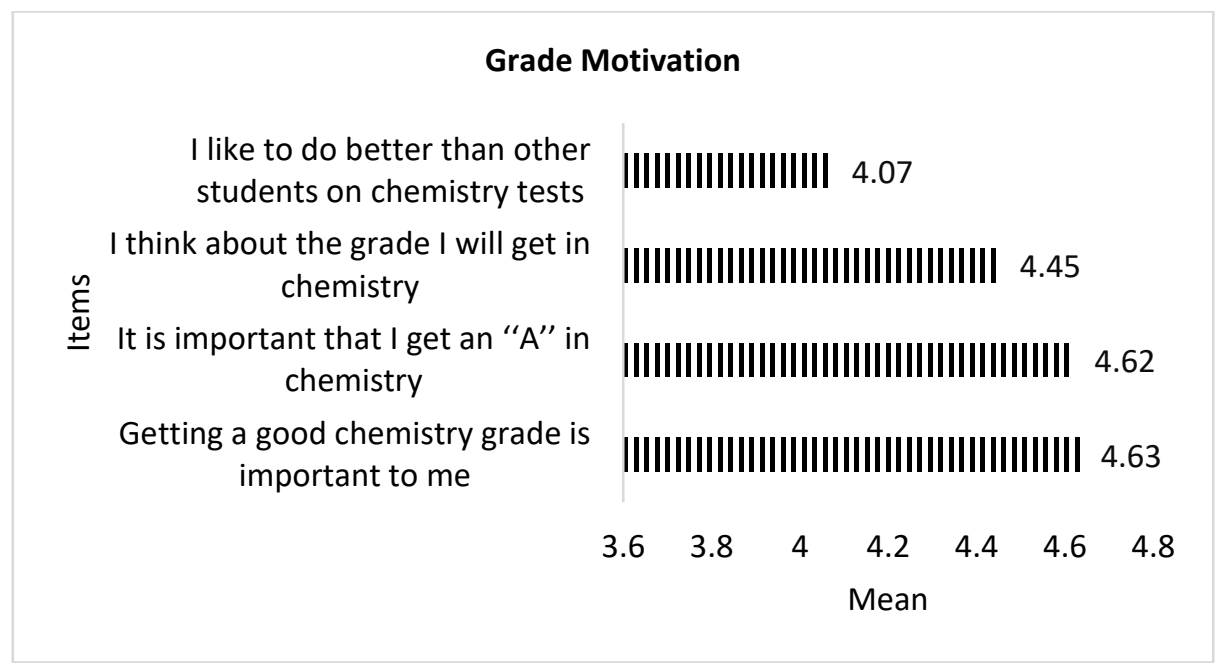

Figure 2. Grade motivation to learn chemistry.

According to Bandura (1986), self-efficacy is defined as individuals' ability in their capability to accomplish a specific task. Self-efficacy has the potential to increases with positive experiences while decreasing negative experiences (Dalgety \& Coll, 2006). Figure 3 represents the result of self-efficacy to learn chemistry among the gifted and talented students. The result shows that the highest mean value (mean=4.48) was obtained on the aspect 'I believe I can master chemistry knowledge and skills'. This shows students have a high level of self-efficacy to 


\section{INTERNATIONAL JOURNAL OF ACADEMIC RESEARCH IN PROGRESSIVE EDUCATION AND DEVELOPMENT}

Vol. 9, No. 2, 2020, E-ISSN: $2226-6348$ @ 2020 HRMARS

spend more time to complete any activities and confronting barriers to master chemistry knowledge and skills. The lowest value (mean=3.55) was observed on 'I am confident I will do well on chemistry tests'. The mean value shows that not all the students have positive selfefficacy and they need to be motivated to gain the confidence to do well in chemistry tests.

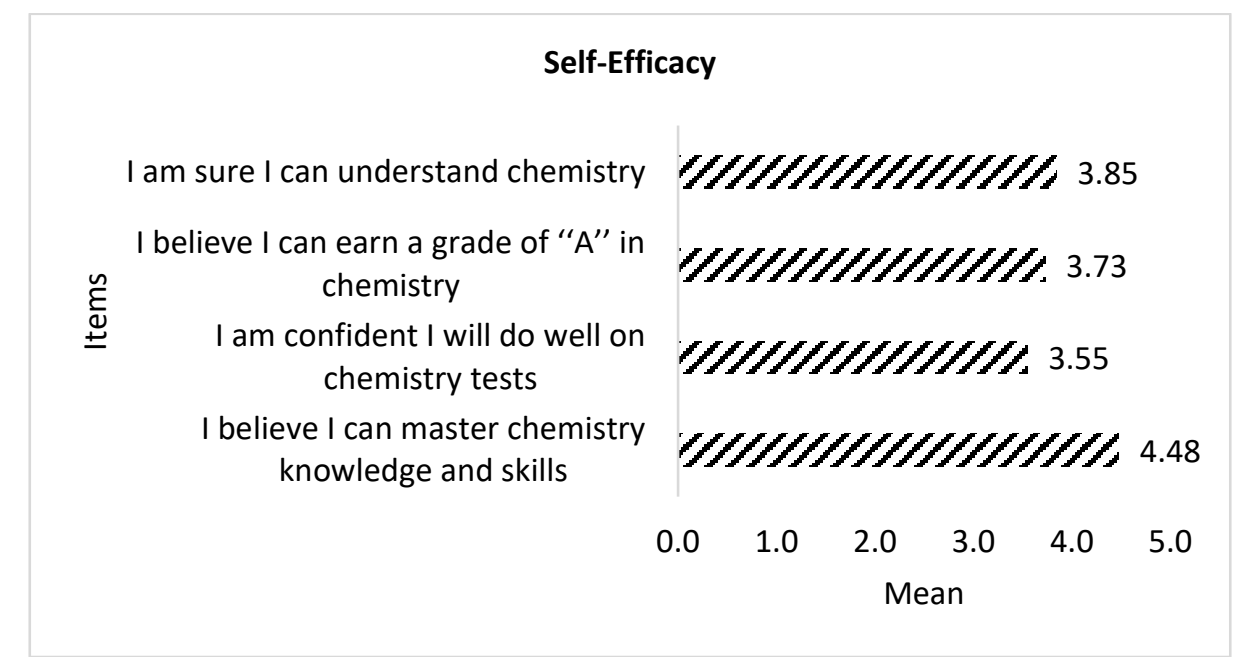

Figure 3. Self-efficacy to learn chemistry.

Figure 4 represents the self-determination of the gifted and talented students to learn chemistry. The highest mean value was observed for the item 'I study hard to learn chemistry' (mean=3.62), on the other hand, the lowest value was obtained for the item 'I use strategies to learn chemistry well' (mean $=3.48$ ). This result indicates that most of the students intended to do well in chemistry by studying hard. Nevertheless, they don't have good strategies to learn chemistry. Thus during the teaching and learning process, the teachers playing an important role to expose students with strategies to learn chemistry.

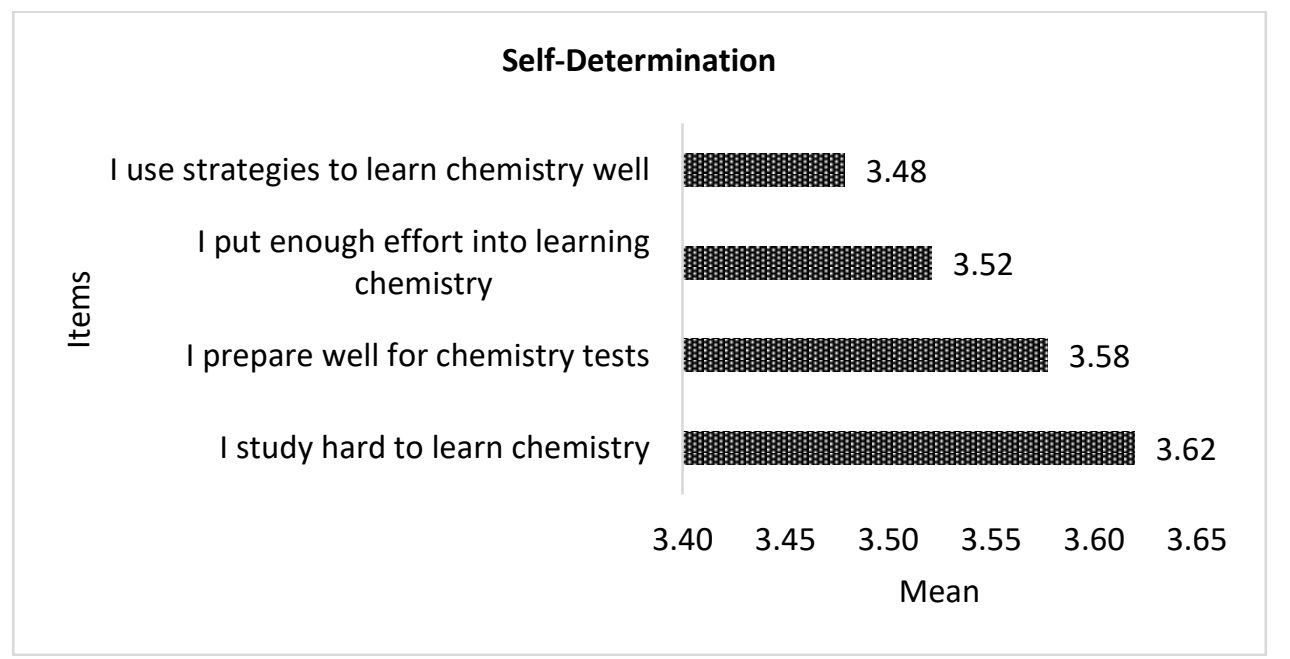

Figure 4. Self-determination to learn chemistry.

Figure 5 represents career motivation, which leads to chemistry learning. It was found that most of the students with the opinion stating that knowing chemistry will give them a career 


\section{INTERNATIONAL JOURNAL OF ACADEMIC RESEARCH IN PROGRESSIVE EDUCATION AND DEVELOPMENT}

Vol. 9, No. 2, 2020, E-ISSN: $2226-6348$ @ 2020 HRMARS

advantage (mean=3.97). This is because chemistry is a central science, where the knowledge of chemistry is crucial to understand other STEM subjects. Moreover, this result is also in agreement with those found by Ardura and Perez-Bitrian (2018) in Spanish secondary school students. Ardura and Perez-Bitrian (2018) argued that career motivation has a significant effect on students' future decisions. Palmer, Burke and Aubusson (2017) also supported that enhancing students' enjoyment, involvement and interpretation in science learning, may result in future choices of science related career. However, the students seem like don't prefer to involve in a career related to chemistry (mean=3.34). The gifted and talented students involved in this research are in the early stage of gaining chemistry knowledge and skills. Thus, it is expected that chemistry knowledge and skills learned at a younger age able to develop their interest in a chemistry career.

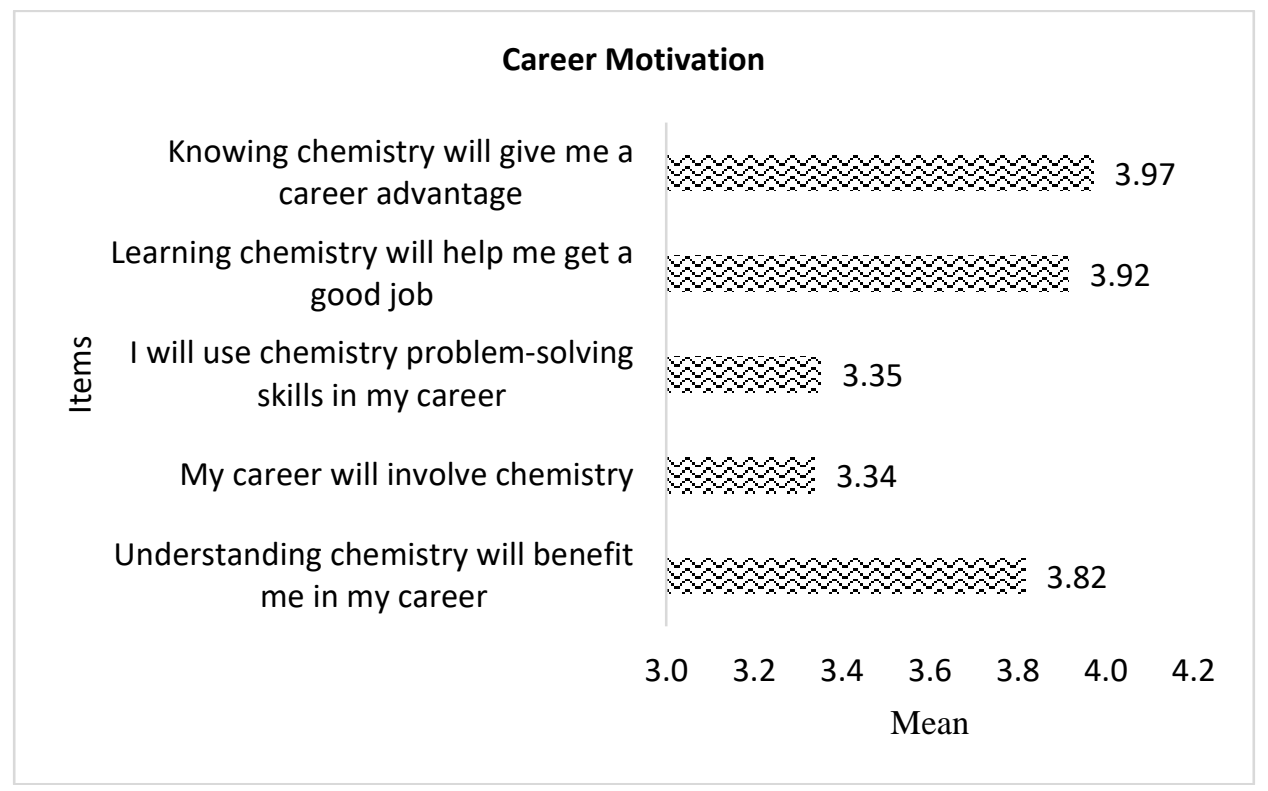

Figure 5. Career motivation to learn chemistry.

Intrinsic motivation is defined as an engagement in behavior that is inherently satisfying or enjoyable (Legault, 2016). The findings of the result (Figure 6) shows the highest mean value was obtained for the item 'learning chemistry is interesting' (mean=4.06). This is because, when intrinsically motivated, a person will move to act for the fun or challenge entailed rather than because of external prods, pressures, or rewards (Ryan \& Deci, 2000). While, item 'learning chemistry makes my life more meaningful' show the lowest mean value, 3.52. This shows that continuous knowledge of chemistry is important to make the students to be aware of the importance of chemistry in our daily life. 
INTERNATIONAL JOURNAL OF ACADEMIC RESEARCH IN PROGRESSIVE EDUCATION AND DEVELOPMENT

Vol. 9, No. 2, 2020, E-ISSN: $2226-6348 @ 2020$ HRMARS

\section{Intrinsic Motivation}

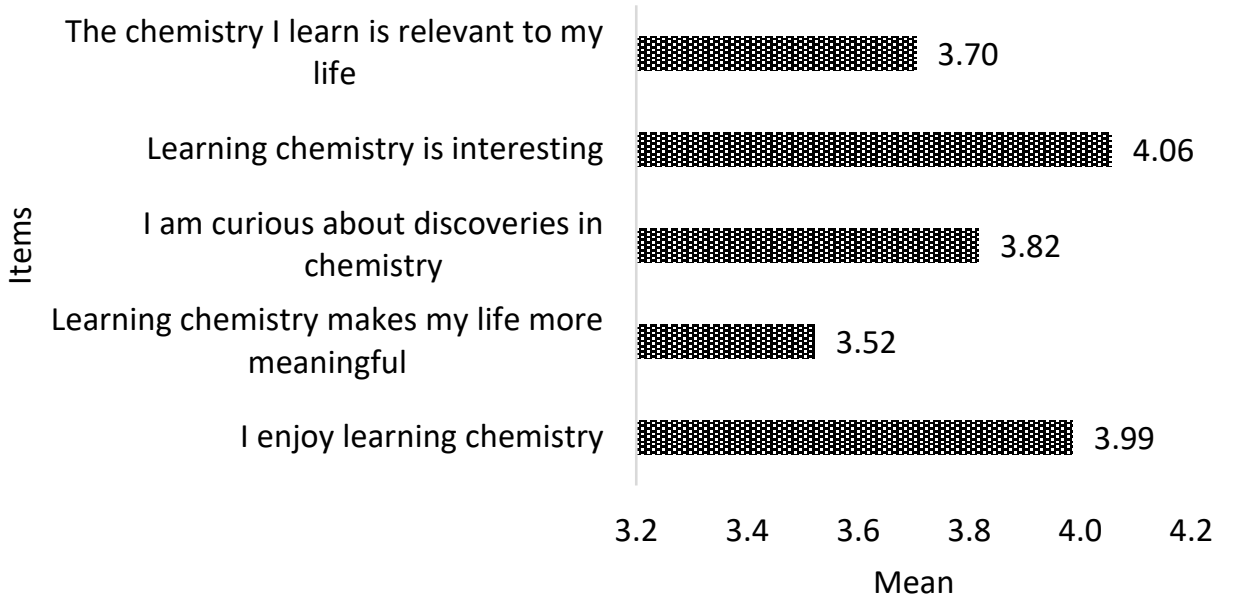

Figure 6. Intrinsic motivation to learn chemistry.

\section{T-test Analysis}

The difference in motivation to learn chemistry among the gifted and talented students based on gender was studied with an independent sample t-test. The result of this analysis is shown in Table 2. For variable use of chemistry knowledge, grade motivation, self-efficacy, selfdetermination, career motivation and intrinsic motivation, the analysis shows that the P-value of the $t$-test is greater than the significance level of $\alpha=0.05(p>0.05)$. The results obtained show that there is no significant difference for all the motivational variables studied based on gender among the gifted students at Pusat GENIUS@pintar Negara. This study is in consistent with Greenfield (1996), who found that there is no gender differences in science related learning between boys and girls. In general, numerous studies have found that in terms of gender, male students are more motivated in learning chemistry than female students, but according to (Shah, Mahmood \& Harrison, 2013) only a minority of studies exist in which no difference was found between genders.

Although there is no significant difference found based on gender, for variable use of chemistry knowledge, grade motivation and career motivation, the female students show higher mean value compared to the male students. Eliasson, Sorensen and Karlsson (2016) found that positive attitudes towards science and higher achievements in science were better among female students than male students. This is because female students were found to have better skills in identifying problems, giving statements and questions, explaining concepts, giving reasons and opinions, and the ability to make conclusions than men (Perdana, Budiyono, Sajidan \& Sukarmin, 2019). In terms of career motivation, this finding contradicts the finding of Busolo (2010). Busolo (2010) found that students showed an interest in future chemistry careers. However, fewer female students were found to be engage in a chemistry career compare to male students.

On the other hand, in terms of self-efficacy, self-determination and intrinsic motivation, the male students show relatively high mean value than the female students. Kinsella (1998) reported that female students have lower self-efficacy in Mathematics and Science compared to 
male students. This suggests that people with higher self-efficacy are more likely to attempt difficult tasks than those with low self-efficacy (Fairbrother, 2000). Besides that, self-efficacy also found to contribute to performance since self-efficacy effect thought processes, motivation, and behavior of the students (Bandura, 1997). In terms of self-determination, the findings of this study are in contrast to Salta and Koulougliotis (2015), who proposed that the female students of a high school have greater self-determination regardless of age. However, in terms of intrinsic motivation, the findings of this study are in agreement with Liu (2017) who investigated students' basic needs and motivation in chemistry and reported that gender difference in motivation favors male students. Covington (2000) states that intrinsic motivation leads to deeper processing, greater mastery, and better implementation of learning strategies in academic situations. Intrinsically motivated students are found to be more likely to face challenging tasks and possess better in academics than extrinsically motivated students (Walker, Greene \& Mansell, 2006).

Table 2. Difference in knowledge and motivation to learn chemistry among the gifted and talented students based on gender.

\begin{tabular}{|l|l|c|c|c|c|}
\hline \multicolumn{1}{|c|}{ Variable } & Gender & Mean & Std. Deviation & t-value & P-value \\
\hline \multirow{2}{*}{$\begin{array}{l}\text { Use of chemistry } \\
\text { knowledge }\end{array}$} & Male & 3.94 & 0.651 & -0.916 & 0.366 \\
\cline { 2 - 6 } & Female & 4.16 & 0.838 & & \\
\hline \multirow{2}{*}{ Grade motivation } & Male & 4.24 & 0.594 & -1.631 & 0.112 \\
\cline { 2 - 6 } & Female & 4.53 & 0.483 & & \\
\hline \multirow{2}{*}{ Self-defficacy } & Male & 3.64 & 0.700 & 1.474 & 0.149 \\
\cline { 2 - 6 } & Female & 3.26 & 0.882 & & \\
\hline \multirow{2}{*}{ Career motivation } & Male & 3.46 & 0.734 & 0.795 & 0.432 \\
\cline { 2 - 6 } & Female & 3.28 & 0.684 & & \\
\hline \multirow{2}{*}{ Intrinsic motivation } & Male & 3.44 & 1.104 & -0.700 & 0.489 \\
\cline { 2 - 6 } & Female & 3.69 & 1.143 & & \\
\cline { 2 - 6 } & Male & 3.82 & 0.761 & 0.848 & 0.402 \\
\cline { 2 - 6 } & Female & 3.56 & 1.085 & & \\
\hline
\end{tabular}

\section{Pearson's Correlation Analysis}

Table 3 presents the Pearson's correlation analysis between the use of chemistry knowledge, grade motivation, self-efficacy, self-determination, career motivation and intrinsic motivation. A range of moderate to a weak relationship was observed between the variables. However, a relatively negligible relationship was observed self-efficacy and career motivation, with $r=0.286$, $p=0.016$. Results revealed that the highest moderate and significant relationship was obtained between the use of knowledge and career motivation ( $r=0.744, p=0.000)$. Ryan and Deci (2000) define career motivation and achieving a grade as an extrinsic motivation to learn science since it leads to a tangible end or an external reward. Thus, the use of chemistry knowledge has effect students' career decisions. However, it is depending on the type of student and their choice towards their future career. On the other hand, the weakest correlation was observed between student's use of chemistry knowledge and self-efficacy, with $r=0.424, p=0.000)$. Self-efficacy refers to students' confidence level that able to drive them to succeed in science (Ferrell \& Barbera, 2015). This is because the respondents in this study are newly exposed to chemistry 
INTERNATIONAL JOURNAL OF ACADEMIC RESEARCH IN PROGRESSIVE EDUCATION AND

DEVELOPMENT

Vol. 9, No. 2, 2020, E-ISSN: $2226-6348$ @ 2020 HRMARS

knowledge. Thus, the level of the students' knowledge found to be insufficient to build their selfefficacy, which leads to the lowest correlation.

Table 3. Variable correlation analysis between use of chemistry knowledge, grade motivation, self-efficacy, self-determination, career motivation and intrinsic motivation.

\section{Conclusions}

\begin{tabular}{|l|c|c|c|c|c|c|}
\hline & UCK & GM & SE & SD & CM & IM \\
\hline $\begin{array}{l}\text { Use of chemistry } \\
\text { knowledge (UCK) }\end{array}$ & 1 & $0.424^{* *}$ & $0.333^{* *}$ & $0.565^{* *}$ & $0.744^{* *}$ & $0.597^{* *}$ \\
\hline $\begin{array}{l}\text { Grade motivation } \\
\text { (GM) }\end{array}$ & $0.424^{* *}$ & 1 & $0.334^{* *}$ & $0.533^{* *}$ & $0.450^{* *}$ & $0.471^{* *}$ \\
\hline Self-efficacy (SE) & $0.333^{* *}$ & $0.334^{* *}$ & 1 & $0.483^{* *}$ & $0.286^{*}$ & $0.453^{* *}$ \\
\hline $\begin{array}{l}\text { Self-determination } \\
\text { (SD) }\end{array}$ & $0.565^{* *}$ & $0.533^{* *}$ & $0.483^{* *}$ & 1 & $0.524^{* *}$ & $0.691^{* *}$ \\
\hline $\begin{array}{l}\text { Career motivation } \\
\text { (CM) }\end{array}$ & $0.744^{* *}$ & $0.450^{* *}$ & $0.286^{*}$ & $0.524^{* *}$ & 1 & $0.539^{* *}$ \\
\hline $\begin{array}{l}\text { Intrinsic motivation } \\
\text { (IM) }\end{array}$ & $0.597^{* *}$ & $0.471^{* *}$ & $0.453^{* *}$ & $0.691^{* *}$ & $0.539^{* *}$ & 1 \\
\hline a $*$ p $<0.05 ; * * p<0.01$. & & & & \\
\hline
\end{tabular}

Generally, students' scientific literacy highly depends on the role of science teachers, and academic advisors to stimulate their motivation to learn science. Thus, the present research aimed to study the knowledge and motivation for learning chemistry among gifted and talented students at Pusat GENIUS@pintar Negara to serve as a guide for chemistry educators. The gifted and talented students' perceived chemistry knowledge is useful to interpret many aspects of everyday life. Besides that, the findings also indicate that the gifted and talented students are more confidents with their own abilities to learn chemistry to obtain good grade and provide a good career pathway for their future.

The results obtained from this study provide baseline data for educators to promote academic motivation to learn chemistry among the gifted student, particularly for the younger age group students. Planning, teaching and learning of chemistry subject need to focus on fostering students' intrinsic and extrinsic motivation. Interventions in chemistry teaching by the instructor and conducive learning environment for the students to boost intrinsic and extrinsic motivation to achieve greater success. In fact, students should also be exposed to active learning strategies, or student centred learning, connecting chemistry content with empirical application of knowledge is required to fulfil the Z-generation students learning ability.

\section{Acknowledgement}

The author would like to acknowledge the students, teachers and schools involved in the data gathering for their help and generous support. 
INTERNATIONAL JOURNAL OF ACADEMIC RESEARCH IN PROGRESSIVE EDUCATION AND

DEVELOPMENT

Vol. 9, No. 2, 2020, E-ISSN: $2226-6348 @ 2020$ HRMARS

\section{Corresponding Author}

Suganty A/P Kanapathy

Pusat GENIUS@pintar Negara,

University Kebangsaan Malaysia,

43600 Bangi, Selangor, Malaysia.

Email: sugantyk@ukm.edu.my

\section{References}

After-School Alliance. (2015). Full STEM ahead: afterschool programs step up as key partners in STEM education. Retrieved from http://afterschoolalliance.org/AA3PM/STEM.pdf

Arbona, C. (2000). The development of academic achievement in school aged children: Precursors to career development. In S. D. Brown \& R. W. Lent (Eds.), Handbook of Counseling Psychology (3 ${ }^{\text {rd }}$ ed., pp. 270-309). New York: John Wiley \& Sons Inc.

Ardura, D., \& Perez-Bitrian, A. (2018). The effect of motivation on the choice of chemistry in secondary schools: adaptation and validation of the Science Motivation Questionnaire II to Spanish students. Chemistry Education Research and Practices, 19(3), 905-918. https://doi.org/10.1039/C8RP00098K

Bandura, A. (1986). Social foundations of thought and action: A social cognitive theory. Englewood Cliffs, NJ: Prentice-Hall.

Bandura, A. (2001). Social cognitive theory: An agentive perspective. Annual Review of Psychology, 52(1), 1-26. https://doi.org/10.1146/annurev.psych.52.1.1

Black, A. E., \& Deci, E. L. (2000). The effects of instructors' autonomy support and students' autonomous motivation on learning organic chemistry: A self-determination theory perspective. Science Education, 84(6), 740-756. https://doi.org/10.1002/1098237X(200011)84:6<740::AID-SCE4>3.0.CO;2-3

Blotnicky, K. A., Franz-Odendaal, T., French, F., \& Joy, P. (2018). A study of the correlation between STEM career knowledge, mathematics self-efficacy, career interests, and career activities on the likelihood of pursuing a STEM career among middle school students. International Journal of STEM Education, 5(1), 1-15.

Broman, K., Ekborg, M., \& Johnels, D. (2011). Chemistry in crisis? Perspectives on teaching and learning chemistry in Swedish upper secondary schools. Nordina, 7(1), 43-60. https://doi.org/10.5617/nordina.245

Brophy, J. (2004). Motivating students to learn. Mahwah, NJ: Erlbaum.

Busolo, A. J. (2010). Gender differences in students' achievement in chemistry in secondary schools of Kakamega district, Kenya (Master thesis, Kenyatta University Nairobi City, Kenya). Retrieved from https://pdfs.semanticscholar.org/3ef2/b52f0aa96547681200f7ef84363077f27f96.p

Cheung, D. (2009). Developing a scale to measure students' attitudes toward chemistry lessons. International Journal of Science Education, 31(16), 2185-2203. https://doi.org/10.1080/09500690802189799

Covington, M. V. (2000). Goal theory, motivation and school achievement: An integrative review. Annual Review of Psychology, 51(2), 171-200.

https://doi.org/10.1146/annurev.psych.51.1.171 
Dalgety, J., \& Coll, R. K. (2006). The influence of first year chemistry students' learning experiences on their educational choices. Assessment and Evaluation in Higher Education, 31(3), 303-328. https://doi.org/10.1080/02602930500352931

Eliasson, N., Sorensen, H., \& Karlsson, K. G. (2016). Teacher-student interaction in contemporary science classrooms: is participation still a question of gender?. International Journal of Science Education, 38(16), 1655-1672. https://doi.org/10.1080/09500693.2016.1213457

Fairbrother, R. (2000). Strategies for learning. In M. Monk, \& J. Osborne (Eds.), Good Practice in Science Teaching: What Research has to Say (pp. 7-24). Philadelphia: Open University Press.

Ferrell, B., \& Barbera, J. (2015). Analysis of students' self-efficacy, interest, and effort beliefs in general chemistry. Chemistry Education Research and Practices, 16(2), 318-337. https://doi.org/10.1039/C4RP00152D

Gambari, I. A., Gbodi, B. E., Olakanmi, E. U., \& Abalaka E. N. (2016). Promoting intrinsic and extrinsic motivation among chemistry students using computer assisted instruction. Contemporary Educational Technology, 7(1), 25-46.

https://doi.org/10.1080/09751122.2016.11890422

George, R. (2006). A cross-domain analysis of change in students' attitudes toward science and attitudes about the utility of science. International Journal of Science Education, 28(1), 571-589. https://doi.org/10.1080/09500690500338755

Glynn, S. M., Taasoobshirazi, G., \& Brickman, P. (2007). Non-science majors learning science: A theoretical model of motivation. Journal of Research in Science Teaching, 44(8), 1088-1107. https://doi.org/10.1002/tea.20181

Glynn, S. M., Taasoobshirazi, G., \& Brickman, P. (2009). Science motivation questionnaire: Construct validation with non-science majors. Journal of Research in Science Teaching, 46(2), 127-146. https://doi.org/10.1002/tea.20267

Glynn, S. M., Brickman, P., Armstrong, N., \& Taasoobshirazi, G. (2011). Science motivation questionnaire II: Validation with science majors and non-science majors. Journal of Research in Science Teaching, 48(10), 1159-1176. https://doi.org/10.1002/tea.20442

Greenfield, T. A. (1996). Gender, ethnicity, science achievement, and attitudes. Journal of Research in Science Teaching, 33(8), 901-933. https://doi.org/10.1002/(SICI)10982736(199610)33:8<901::AID-TEA5>3.0.CO;2-\%23

Hassan, A. A., Ali, H. I., Salum, A. A., Kassim, A. M., Elmoge, Y. N., \& Amour, A. A. (2015). Factors affecting students' performance in chemistry: Case study in Zanzibar secondary schools. International Journal of Social, Behavioral, Educational, Economic, Business and Industrial Engineering, 9(11), 4055-4062. https://doi.org/10.5281/zenodo.1339632

Hofstein, A., Eilks, I., \& Bybee, R. (2011). Societal issues and their importance for contemporary science education: A pedagogical justification and the state of the art in Israel, Germany, and the USA. International Journal of Science, Mathematics and Education, 9(1), 1459-1483. https://doi.org/10.1007/s10763-010-9273-9

Jimoh, A. (2005). Perception of difficult topics in chemistry curriculum by students in Nigeria secondary schools. World Journal of Education, 1(2), 71-78. 
Kinsella, S. (1998). A cross discipline study of traditional and non-traditional college students. College Student Journal, 32(4), 532-538.

Kolomuc, A., \& Tekin, S. (2011). Chemistry teachers' misconceptions concerning concept of chemical reaction rate. Eurasian Journal of Chemistry Education, 3(2), 84-101.

Legault, L. (2016). Intrinsic and extrinsic motivation. In V. Zeigler-Hill, \& T. Shackelford (Eds.), Encyclopedia of Personality and Individual Differences (pp.1-4). Cham, Switzerland: Springer.

Liu, Y. (2017). Investigating students' basic needs and motivation in college chemistry courses with the lens of self-determination theory (Dissertation, University of South Florida, Tampa, US). Retrieved from https://scholarcommons.usf.edu/cgi/viewcontent.cgi?article=8084\&context=etd

Loof, D. H., Struyf, A., Boeve-de Pauw, J., \& Petegam, P. V. (2019). Teachers' motivating style and students' motivation and engagement in STEM: The relationship between three key educational concepts. Research in Science Education, 49(142), 1-19. https://doi.org/10.1007/s11165-019-9830-3

Mazlo, J., Dormedy, D., Neimoth-Anderson, J., Urlacher, T., Carson, G., Haas, E. J., \& Kelter, P. (2002). What motivates students in the lab? Assessment of motivational methods in the general chemistry laboratory. Journal of College Science Teaching, 31(5), 318-321.

Meng, C. C., Idris, N., \& Eu, L. K. (2014). Secondary students' perceptions of assessments in Science, Technology, Engineering, and Mathematics (STEM). Eurasia Journal of Mathematics, Science and Technology Education, 10(3), 219-227.

https://doi.org/10.12973/eurasia.2014.1070a

Ministry of Education Malaysia. (2016). Implementation Guide for Science, Technology, Engineering, and Mathematics (STEM) in Teaching and Learning. Putrajaya: MOE.

Ministry of Education. (2013). Malaysia Education Blueprint 2013-2025 (Preschool to PostSecondary Education). Putrajaya: MOE.

Nakhleh, M. B. (1992). Why some students don't learn chemistry: Chemical misconceptions. Journal of Chemistry Education, 69(3), 191-196. https://doi.org/10.1021/ed069p191

National Research Council. (2009). Learning science in informal environments: people, places, and pursuits. Washington, DC: The National Academies Press.

Olic, S., Adamov, J., \& Babić-Kekez, S. (2014). Motivation as a predictor of pupil's achievement in chemistry. Research in Pedagogy, 4(2), 24-36.

Orvis, J. N., Sturges, D., Tysinger, P. D., Riggins, K., \& Landge, S. (2018). A culture of extrinsically motivated students: Chemistry. Journal of the Scholarship of Teaching and Learning, 18(1), 43-57. https://doi: 10.14434/josotl.v18i1.21427

Palmer, T. A., Burke, P. F., \& Aubusson, P. (2017). Why school students choose and reject science: A study of the factors that students consider when selecting subjects. International Journal of Science Education, 39(6), 645-662. https://doi.org/10.1080/09500693.2017.1299949

Perdana, R., Budiyono, S., \& Sukarmin. (2019). Analysis of student critical and creative thinking (CCT) skills on chemistry: A study of gender differences. Journal of Educational and Social Research, 9(4), 43-52.

https://www.mcser.org/journal/index.php/jesr/article/view/10530 
Pintrich, P. R., \& Schunk, D. H. (2002). Motivation in education: Theory, research, and applications. Upper Saddle River, NJ: Prentice Hall.

Rajendram, R. (2018). Nurturing interest in STEM. The STAR. Retrieved from https://www.thestar.com.my/news/nation/2018/05/16/nurturing-interest-in-stemimprovingteachers\#B1ZcBeDpKttDRS Gw.99

Roy, S. (2016). Chemistry in our daily life: Preliminary information. International Journal of Home Science, 2(3), 361-366.

Ryan, R. M., \& Deci, E. L. (2000). Intrinsic and extrinsic motivations: Classic definitions and new directions. Contemporary Educational Psychology, 25(1), 54-67. https://doi.org/10.1006/ceps.1999.1020

Saribiyik, S., Altunçekiç, A., \& Yaman, S. (2004). A study on the research of teacher candidate's interest level and problem solving ability for science education course (in Turkish). Proceedings of the XIII National Educational Science Conference. Malatya, Turkey.

Salta, K., \& Koulougliotis, D. (2015). Assessing motivation to learn chemistry: adaptation and validation of Science Motivation Questionnaire II with Greek secondary school students. Chemistry Education Research and Practice, 16(2), 237-250. https://doi.org/10.1039/C4RP00196F

Samat, N. A. A., Ibrahim, N. H., Surif, J., Ali, M., Abdullah, A. H., Talib, C. A., \& Bunyamin, M. A. H. (2019). Chem-A module based on STEM approach in chemical bond. International Journal of Recent Technology in Engineering, 7(6S5), 700-710.

Schumm, M. F., \& Bogner, F. X. (2016). Measuring adolescent science motivation. International Journal of Science Education, 38(3), 434-449.

https://doi.org/10.1080/09500693.2016.1147659

Shah, Z. A, Mahmood, N., \& Harrison, C. (2013). Attitude towards science learning: an exploration of Pakistani students. Journal of Turkish Science Education, 10(2), 35-47. https://ssrn.com/abstract $=2362324$

Shin, S., Lee, J. K., \& Ha, M. (2017). Influence of career motivation on science learning in Korean high school students. Journal of Mathematics, Science, Technology and Education, 13(5), 1517-1538. https://doi.org/10.12973/eurasia.2017.00683a

Sisk, D. (2009). Myth 13: The regular classroom teacher can "go it alone". Gifted Child Quarterly, 53(4), 269-271. https://doi.org/10.1177/0016986209346939

Taber, K. (2017). The use of Cronbach's Alpha when developing and reporting research instruments in science education. Research in Science Education, 48(6), 1273-1296. https://doi.org/10.1007/s11165-016-9602-2

Walker, C. O., Greene, B. A., \& Mansell, R. A. (2006). Identification with academics, intrinsic/ extrinsic motivation and self-efficacy as predictors of cognitive engagement. Learning and Individual Differences, 16(1), 1-12. https://doi.org/10.1016/j.lindif.2005.06.004

Wallace, B, Bernardelli, A, Molyneux, C., Farrell, C., Wallace, B., \& Eriksson, G. (2012). Thinking actively in a social context. A universal problem-solving process: a powerful tool to promote differentiated learning experiences. Gifted Education International, 28(1), 58-83. https://doi.org/10.1177/0261429411427645 
INTERNATIONAL JOURNAL OF ACADEMIC RESEARCH IN PROGRESSIVE EDUCATION AND

DEVELOPMENT

Vol. 9, No. 2, 2020, E-ISSN: 2226-6348 @ 2020 HRMARS

Ware, S. A. (2001). Teaching chemistry from a societal perspective. Pure and Applied Chemistry, 73(7), 1209-1214.

Zusho, A., Pintrich, P. R., \& Coppola, B. (2003). Skill and will: The role of motivation and cognition in the learning of college chemistry. International Journal of Science Education, 25(1), 1081-1094. https://doi.org/10.1080/0950069032000052207 